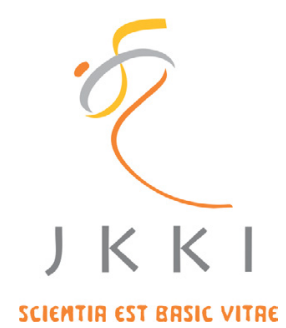

Jurnal Kedokteran dan Kesehatan Indonesia

Indonesian Journal of Medicine and Health

Journal homepage : www.journal.uii.ac.id/index.php/JKKI

\title{
Distribution and determinant of hypertension in Sambirejo district, regency of Sragen 2016
}

Pariawan Lutfi Ghazali

${ }^{1}$ Department of Public Health, Faculty of Medicine, Universitas Islam Indonesia, Yogyakarta, Indonesia

Original Article

\begin{tabular}{l}
\hline ART IC L E I N F O \\
\hline Keywords: \\
hypertension, \\
distribution, \\
determinant \\
*Corresponding author: \\
elghazali1711@gmail.com \\
\hline DOI: 10.20885/JKKI.Vol10.Iss1.art6 \\
\hline History: \\
Received: December 12, 2018 \\
Accepted: March 27, 2019 \\
Online: April 30, 2019 \\
\hline
\end{tabular}

Copyright@2019 Authors. This is an open access article distributed under the terms of the Creative Commons Attribution-NonCommercial $\quad 4.0$ International Licence (http:// creativecommons.org/licences/ by-nc/4.0/).

\section{ABSTRACT}

Background: One of the most prevalent degenerative diseases is hypertension. The statistic data of Sambirejo sub-district of Sragen Regency shows that hypertension is the disease with the second largest number of patients. Research on the distribution and determinant of hypertension needs to be done to support intervention efforts.

Objective: This study aims to determine the distribution and determinants of hypertension in Sambirejo sub-district, Sragen Regency.

Methods: This observational study used a cross-sectional design, with descriptive analytic types. The sample was taken using a stratified random sampling technique. Blood pressure measurements using sphygmomanometer, and other data obtained from questionnaires and direct measurements. We tested the relationship between variables with Kruskal-Wallis bivariate analysis. The multivariate analysis used is Ordinal Regression. Data were statistically significant if $p<0.05$ (CI: 95\%).

Results: The study sample was 454 people. Respondents who experienced hypertension were very high at $57.2 \%$. Hypertension is more prevalent in men, and ages 40 and above. Determinant factors of hypertension are age, gender, genetics, exercise habits, smoking habits, fruit and vegetable consumption, and body mass index. Multivariate analysis with ordinal regression test showed the factors to influence the hypertension were genetic factors $(\mathrm{OR}=4,777 ; 95 \% \mathrm{CI} 3,232-7,059 ; \mathrm{p}=0,000)$, smoking $(\mathrm{OR}=1,004,95 \% \mathrm{CI}: 1,003-1,004, \mathrm{p}=0,0001)$, and body mass index. (OR=1,054; 95\%CI:1,002 - 1,109, $\mathrm{p}=0,042$ ).

Conclusion: Hypertension distribution is more dominant in the male group, and $\geq 40$ years of age. Determinants of hypertension are age, sex, genetics, exercise habits, smoking habits, fruit and vegetable consumption, and body mass index. Genetic factors are the dominant determinant for hypertention.

Latar Belakang: Salah satu penyakit degeneratif dominan adalah hipertensi. Data statistik kecamatan Sambirejo kabupaten Sragen menunjukkan bahwa hipertensi merupakan penyakit dengan jumlah penderita kedua terbesar. Penelitian tentang distribusi dan determinan hipertensi perlu dilakukan untuk mendukung upaya intervensi.

Tujuan: Penelitian ini bertujuan untuk mengetahui distribusi dan determinan Hipertensi di kecamatan Sambirejo Kabupaten Sragen.

Metode: Penelitian observasional ini menggunakan rancangan potong lintang, dengan jenis deskriptif analitik. Sampel diambil dengan teknik stratified random sampling. Pengukuran tekanan darah 
menggunakan sphigmomanometer, data lain didapatkan dari kuesioner dan pengukuran langsung. Uji hubungan antar variabel dengan analisis bivariate Kruskal-Wallis. Analisis multivariatyang digunakan adalah Regresi Ordinal. Data dinyatakan bermakna secara statistik jika $p<0.05$ (CI : 95\%).

Hasil: Sampel penelitian berjumlah 454 orang. Responden yang mengalami hipertensi sangat tinggi yaitu 57,2\% Hipertensi lebih banyak dialami oleh laki-laki, dan usia 40 tahun ke atas. Determinanhipertensi adalah usia, jenis kelamin, genetik, kebiasaan olah raga, kebiasaan merokok, konsumsi buah dan sayur, dan indeks massa tubuh $(p<0,05)$. Analisis multivariat dengan uji regresi ordinal, menunjukkan bahwa faktor yang paling mempengaruhi terjadinya hipertensi adalah faktor genetik (OR=4,777; 95\% CI 3,232-7,059; $p=0,000)$, merokok (OR=1,004,95\%CI: 1,003 - 1,004, $p=0,0001)$, dan indeks masa tubuh (OR=1,054; 95\%CI:1,002 - 1,109, $p=0,042$ ).

Kesimpulan: Distribusi hipertensi lebih dominan di kelompok laki-laki, dan kelompok usia 40 tahun ke atas. Determinan Hipertensi adalah usia, jenis kelamin, genetik, kebiasaan olah raga, kebiasaan merokok, konsumsi buah dan sayur, dan indeks massa tubuh. Faktor genetik merupakan determinan paling dominan.

\section{INTRODUCTION}

The transition of demographics and technology in developing countries including Indonesia, have resulted in epidemiological changes in disease patterns from infectious diseases to non-communicable diseases. This epidemiological transition is caused by changes in socioeconomic, environmental and population structures. Moreover, recent society have adopted unhealthy lifestyles such as smoking, lack of physical activities, high fat and calories food, and consumption of alcohol which are the known risk factors for the non-communicable diseases. ${ }^{1}$

One of the significant health problem and the highest non-communicable diseases in the world is hypertension. According to the International Society of Hypertension (ISH) and the World Health Organization (WHO), people with hypertension have reached 600 million people worldwide, and 3 million of them die every year.
In Indonesia, hypertension is the third cause of death following stroke and tuberculosis, with a prevalence of $25.8 \%$ of the total adult population. Data from Sambirejo Community Health Center in Sragen Regency shows that hypertension is the second largest disease in 2015 and 2016.

Chronic hypertension may lead to complications of more severe diseases such as kidney failure, heart failure, retinopathy, stroke and other vascular diseases. Data shows that the biggest health costs insured by the government are due to heart disease and chronic kidney failure which are often resulted from hypertension. These conditions may dampen productivity and become burdens on families and countries.

Many factors that influence the incidence of hypertension, such as exercise, food intake, smoking, body weight and stress factors. Understanding the determinants of hypertension is one of the first steps to planning a preventive program on the incidence of hypertension in Indonesia. ${ }^{4}$ The closest public health centres in the community such as primary health services are expected to be the foundation for hypertension problem management. This study is expected to play a significant effort to solve hypertension problems by employing intervention programs based on scientific data.

\section{METHODS}

This observational study used a crosssectional design, with a descriptive-analytic method. This research was carried out in the entire Sambirejo District, Sragen Regency, Central Java Province from October to November 2016. The population of this study was all the Sambirejo sub-district residents, totalling 35,715 people, consisting of 17,459 men and 18,256 women. The inclusion criteria for the study population were $\geq 25$ years of age, willing to be the research subjects, resided in Sambirejo sub-district, while the exclusion criteria were psychosis, malignancy, and pregnant.

The minimum sample was calculated based on the Slovin formula $\mathrm{n}=\mathrm{N} /\left(1+\left(\mathrm{N} \mathrm{x} \mathrm{e}^{2}\right)\right)$, in which $\mathrm{n}$ is the minimum sample, $\mathrm{N}$ is the 
number of population, and e is the margin of error. ${ }^{5}$ Based on this formula, the minimum number of samples needed in the study was 396 people. By using the stratified random sampling technique and referring to the inclusion and exclusion criteria, a sample of 454 people was obtained, proportionally distributed in 9 villages according to the number of villagers.

This study took the independent variable data consisting of the characteristics distribution of the subjects, including gender, age, height, weight and hypertension determinants, including hereditary, physical activity, smoking, body mass index, fruit and vegetable consumption. Physical activity is measured by the standards of the Ministry of Health of the Republic of Indonesia, defined as everybody movement that increases energy expenditure and burning, which is doing physical exercise or exercise for 30 minutes every day or at least 3-5 days a week. ${ }^{6}$ The smoking category refers to the Brikman index as mild smokers (1-10 cigarettes per day), moderate smokers (11-20 cigarettes per day) and heavy smokers (more $>20$ cigarettes per day). ${ }^{7}$ Measurements and categories of Body Mass Index using WHO standard 8, i.e. Weight (in Kg) / (Height in Cm). ${ }^{2}$ Consumption of fruits and vegetables refers to the standard of the Ministry of Health of the Republic of Indonesia, which is 400-600 grams per day, consisting of 2 / 3 vegetables and 1/3 pieces. The dependent variable in this study was blood pressure which refers to the Joint National Committee on Prevention, Detection, Evaluation and Treatment of High Blood Pressure (JNC 8). ${ }^{10}$ Blood pressure data was taken from the average of two measurements with a range of 5 minutes (rest) in a sitting position. Meanwhile, other data were obtained from questionnaires and direct measurements. The devices used in this study were sphygmomanometer, portable stadiometer (cm scale), and standard scale ( $\mathrm{kg}$ scale) to measure blood pressure, body height and weight respectively.

Intercorrelation test between variables was analysed using One Way ANOVA bivariate test, with Kruskal-Wallis alternative test. Multivariate analysis was performed using Ordinal Regression, with the level of significance used was 0.05 .

\section{RESULTS}

Blood pressure measurements in 454 research subjects showed that more than $50 \%$ of the adult population of the Sambirejo subdistrict had hypertension, as shown in Table 1.

Table 1. Distribution of Blood Pressure Population of Sambirejo District in 2016

\begin{tabular}{lcc}
\hline \multicolumn{1}{c}{ Classification } & Total & Percentage (\%) \\
\hline Normal & 92 & 20,3 \\
Prehypertension & 102 & 22,5 \\
Hypertension, grade I & 170 & 37,4 \\
Hypertension, grade II & 90 & 19,8 \\
\hline
\end{tabular}

Distribution data and hypertension determinant in the research subjects were processed by univariate analysis to show the distribution and frequency. This study indicated that the number of research subjects with more body weight and obesity is quite high (36.3\% and 9.5\%) while research subjects who performed physical activity according to WHO recommendations were very few $(2 \%)$, whereas the number of subjects who smoked was quite high $(60 \%)$. The results of univariate analysis are presented in table 2.

The normality test on blood pressure data was carried out using the Kolmogorov-Smirnov = test. It was found that the data were not normally distributed $(\mathrm{p}<0.05)$. Therefore, the bivariate analysis was performed using the KruskalWallis test. The distribution of research subjects 
based on independent variables and dependent variables and the results of bivariate analysis are shown in Table 3. As shown in table 3, men have higher hypertension incidence (63\%) than women (46.2\%). Majority of the age was between 40 and 60 years, and more patients have a family history of hypertension.

Table 2. Univariate Analysis of Independent Variables

\begin{tabular}{|c|c|c|}
\hline Variable & Frequency & Percentage \\
\hline \multicolumn{3}{|l|}{ Sex } \\
\hline Male & 298 & $65,6 \%$ \\
\hline Female & 156 & $34,4 \%$ \\
\hline \multicolumn{3}{|l|}{ Age (year) } \\
\hline$<30$ & 8 & $1,8 \%$ \\
\hline 30 to $<40$ & 70 & $15,4 \%$ \\
\hline 40 to $<50$ & 117 & $25,8 \%$ \\
\hline 50 to $<60$ & 137 & $30,2 \%$ \\
\hline 60 or over & 122 & $26,9 \%$ \\
\hline \multicolumn{3}{|l|}{ Body Mass Index } \\
\hline Underweight & 21 & $4,6 \%$ \\
\hline Normal & 225 & $49,6 \%$ \\
\hline Overweight & 165 & $36,3 \%$ \\
\hline Obesity & 43 & $9,5 \%$ \\
\hline \multicolumn{3}{|c|}{ Hereditary/genetic predisposition } \\
\hline Present & 238 & $52,4 \%$ \\
\hline Absent & 216 & $47,6 \%$ \\
\hline \multicolumn{3}{|l|}{ Physical Activity } \\
\hline As recommended & 9 & $2 \%$ \\
\hline Low & 377 & $83 \%$ \\
\hline Absent & 68 & $15 \%$ \\
\hline \multicolumn{3}{|l|}{ Smoking } \\
\hline Non smoker & 177 & $39,0 \%$ \\
\hline Mild & 43 & $9,5 \%$ \\
\hline Moderate & 148 & $32,6 \%$ \\
\hline Heavy & 86 & $18,9 \%$ \\
\hline \multicolumn{3}{|c|}{ Fruit and vegetable consumption } \\
\hline$\leq 2$ portion perday & 330 & $72,7 \%$ \\
\hline $3-4$ portion perday & 122 & $26,9 \%$ \\
\hline$\geq 5$ portion perday & 2 & $0,4 \%$ \\
\hline
\end{tabular}


Table 3. Cross Tabulation and Bivariate Analysis with the Kruskal-Wallis Test

\begin{tabular}{|c|c|c|c|c|c|c|c|c|c|}
\hline \multirow{2}{*}{ Variable } & \multicolumn{2}{|c|}{ Normal } & \multicolumn{2}{|c|}{ Pre-HT } & \multicolumn{2}{|c|}{ HT I } & \multicolumn{2}{|c|}{ HT II } & \multirow{2}{*}{$\mathbf{p}$} \\
\hline & $\mathbf{n}$ & $\%$ & $\mathbf{n}$ & $\%$ & $\mathbf{n}$ & $\%$ & $\mathbf{n}$ & $\%$ & \\
\hline Sex & & & & & & & & & 0,000 \\
\hline Male & 41 & 13,8 & 69 & 23,2 & 122 & 40,9 & 66 & 22,1 & \\
\hline Female & 51 & 32,7 & 33 & 21,2 & 48 & 30,8 & 24 & 15,4 & \\
\hline Age & & & & & & & & & 0,000 \\
\hline$<30$ & 5 & 62,5 & 0 & 0 & 2 & 25 & 1 & 12,5 & \\
\hline 30 to $<40$ & 20 & 28,6 & 31 & 44,3 & 15 & 21,4 & 4 & 5,7 & \\
\hline 40 to $<50$ & 18 & 15,4 & 39 & 33,3 & 27 & 23,1 & 33 & 28,2 & \\
\hline 50 to $<60$ & 36 & 26,3 & 16 & 11,7 & 56 & 40,9 & 29 & 21,2 & \\
\hline 60 or over & 92 & 20,3 & 102 & 22,2 & 170 & 37,4 & 90 & 19,8 & \\
\hline Body Mass Index & & & & & & & & & 0,000 \\
\hline Underweight & 8 & 38,1 & 2 & 9,5 & 8 & 38,1 & 3 & 14,3 & \\
\hline Normal & 63 & 28,0 & 54 & 24,0 & 78 & 34,7 & 30 & 13,3 & \\
\hline Overweight & 19 & 11,5 & 45 & 27,3 & 55 & 33,3 & 46 & 27,9 & \\
\hline Obesity & 2 & 4,7 & 1 & 2,3 & 29 & 67,4 & 11 & 25,6 & \\
\hline Genetic factor & & & & & & & & & 0,000 \\
\hline Present & 15 & 6,3 & 40 & 16,8 & 116 & 48,7 & 67 & 28,2 & \\
\hline Absent & 77 & 35,6 & 62 & 28,7 & 54 & 25,0 & 23 & 10,6 & \\
\hline Physical Activity & & & & & & & & & 0,022 \\
\hline As recommended & 3 & 33,3 & 4 & 44,4 & 2 & 22,2 & 0 & 0 & \\
\hline Low & 75 & 19,9 & 83 & 22,0 & 149 & 39,5 & 70 & 18,6 & \\
\hline Absent & 14 & 20,6 & 15 & 22,1 & 19 & 27,9 & 20 & 29,4 & \\
\hline Smoking status & & & & & & & & & 0,000 \\
\hline Non Smoker & 54 & 30,5 & 42 & 23,7 & 61 & 34,5 & 20 & 11,3 & \\
\hline Mild & 11 & 25,6 & 23 & 53,5 & 9 & 20,9 & 0 & 0 & \\
\hline Moderate & 26 & 17,6 & 32 & 21,6 & 63 & 42,6 & 27 & 18,2 & \\
\hline Heavy & 1 & 1,2 & 5 & 5,8 & 37 & 43,0 & 43 & 50,0 & \\
\hline \multicolumn{5}{|c|}{ Fruit and vegetable consumption } & & & & & 0,000 \\
\hline$\leq 2$ portion per day & 63 & 19,1 & 65 & 19,7 & 120 & 36,4 & 82 & 24,8 & \\
\hline $3-4$ portion per day & 28 & 23 & 36 & 29,5 & 50 & 41,0 & 8 & 6,6 & \\
\hline$\geq 5$ portion per day & 1 & 50 & 1 & 50 & 0 & 0 & 0 & 0 & \\
\hline
\end{tabular}

Multivariate analysis was conducted to find out the influence of the independent variables on the blood pressure. This analysis was carried out using ordinal regression tests (presented in Table 4). Data shows that the factors that influence the occurrence of hypertension in Sambirejo sub-district are higher body weight (or BMI score), smoking history and family history of hypertension. 
Table 4. Results of Multivariate Analysis with Ordinal Regression Test

\begin{tabular}{|c|c|c|c|}
\hline Variable & OR & $95 \% \mathrm{CI}$ & $p$ \\
\hline \multicolumn{4}{|l|}{ Body Mass Index } \\
\hline BMI score & 1,054 & $1,002-1,109$ & 0,042 \\
\hline \multicolumn{4}{|l|}{ Age } \\
\hline Age in year & 1,012 & $0,997-1,027$ & 0,115 \\
\hline \multicolumn{4}{|l|}{ Smoking } \\
\hline Brickman index & 1,004 & $1,003-1,004$ & 0,000 \\
\hline \multicolumn{4}{|l|}{ Genetic factor } \\
\hline Present & 4,777 & $3,232-7,059$ & 0,000 \\
\hline Absent & 1,000 & & \\
\hline \multicolumn{4}{|l|}{ Sex } \\
\hline Male & 0,617 & $0,370-1,028$ & 0,064 \\
\hline Female & 1,000 & & \\
\hline \multicolumn{4}{|l|}{$\begin{array}{l}\text { Fruits and vegetables } \\
\text { consumption }\end{array}$} \\
\hline$\leq 2$ portion per day & 0,975 & $0,044-21,559$ & 0,987 \\
\hline $3-4$ portion per day & 0,625 & $0,028-13,780$ & 0,766 \\
\hline$\geq 5$ portion per day & 1,000 & & \\
\hline \multicolumn{4}{|l|}{ Physical activity } \\
\hline Absent & 3,133 & $0,706-13,904$ & 0,133 \\
\hline Low & 1,886 & $0,446-7,976$ & 0,388 \\
\hline As recommended & 1,000 & & \\
\hline
\end{tabular}

\section{DISCUSSION}

This study showed that men had more hypertension than women. Gender is an essential factor in the regulation of blood pressure due to its influence on the renin-angiotensin system. ${ }^{11}$ Testosterone causes a decrease in the expression of angiotensin II type- 2 receptors which serves as a vasodilator of blood vessels. The low receptors expression in male patients will reduce the ability of vascular vasodilation. ${ }^{12}$ The influence of sex on the hypertension tendency may also be related to behavioural risk factors such as smoking, alcohol consumption, and physical activity. ${ }^{13}$

According to our results, age displays a significant relationship with the occurrence of hypertension. The older generation is directly proportional to the atherossclerosis process and inversely to blood vessel elasticity as the result of blood vessel stiffness. ${ }^{14}$ This, in turn, causes narrowing of the arteries hence increased resistance. This whole event increases in blood pressure.

This study shows there is a significant relationship between Body Mass Index (BMI) and blood pressure. The increased fat cell mass causes increased production of angiotensinogen in fat tissue. This condition plays a vital role in raising blood pressure. ${ }^{14}$ It has been demonstrated that the renin-angiotensin system (RAS) in fat tissue is involved in the pathophysiology of obesity and obesity-related diseases (including hypertension and insulin resistance). Local RAS levels in fat tissue play a role in increasing systemic RAS activity, which will cause an increase in blood pressure. Angiotensin increases in oxidative 
stress in blood vessel endothelial cells. This process will increase in blood pressure. ${ }^{16}$

Various risk factors especially smoking habit have a higher impact on the progression of cardiovascular disease.${ }^{17}$ Accordingly, our study shows there is a relationship between smoking status and blood pressure. Besides, we found a significant correlation between the amounts of cigarettes consumed with hypertension. ${ }^{18}$ In terms of the hereditary factor, this study suggested a significant relationship between genetic factors and blood pressure. Forty-three genetic variants that might be related to blood pressure. ${ }^{18}$ Hypertension can be influenced by these genes that play a role in regulating steroid hormone metabolism (mineralocorticoid receptor activity) and sodium in the kidneys. ${ }^{19,20}$

Consumption of 400-600 grams of fruit and vegetables a day is recommended to prevent hypertension. ${ }^{21}$ Fruits and vegetables contain polyphenols and vitamins that can reduce oxidative stress. These prevent platelet aggregation and inflammation of the blood vessel endothelium. Eventually, this condition will be able to prevent the occurrence of atherosclerosis plaques. ${ }^{22}$ Besides, fruits and vegetables are rich in potassium and calcium which influence the decrease of the sodium level in the blood. Potassium also plays a role in creating an osmotic balance and acid-base balance in body fluids. This also exhibits the ability to strengthen blood vessel walls and maintain its elasticity. ${ }^{23}$ A study suggested that calcium intakes have a protective effect on hypertension and showed a significant difference in diastolic and systolic blood pressure. ${ }^{24}$ This is in line with our study which showed a significant relationship between the consumption of fruits and vegetables with blood pressure.

Exercise is recommended as one of the factors that influence blood pressure. ${ }^{25}$ This study shows a significant relationship between exercise and blood pressure. A recommended exercise is a physical activity that is carried out 3-5 times a week (one day to rest), regularly with moderate intensity. The amount of time in carrying out physical activity begins according to one's physical abilities (between 20-60 minutes) 26 It has been shown that physical activity can improve heart speed during resting conditions, improve lipid profile including LDL levels and reduce systolic and diastolic pressure. Other showed that regular exercise for 6-12 weeks could reduce systolic and diastolic blood pressure by 5-10 mmHg. Performing exercise regularly has been shown to optimise blood pressure. $^{25}$

There are known some factors that influence blood pressure including gender, age, family history, smoking habits, and lifestyle. ${ }^{27} \mathrm{Bad}$ habits are the biggest threat to an individual health condition. Some of these include a nonhealthy modern lifestyle, hard work in stressful situations, prolonged stress, wrong management of stress (overcoming stress by smoking or drinking alcoholic beverages or coffee), and sedentary lifestyle. ${ }^{27}$ The Indonesian Family Life Survey (IFLS-5) data showed that depression symptoms are positively related to the incidence of hypertension. ${ }^{28}$

Meanwhile, this study suggests some variables that simultaneously affect blood pressure, which are body mass index, smoking and genetic factors. However, hypertension tends to be multifactorial with dominance and can be different for each. ${ }^{27}$ Although genetic factors cannot be modified, efforts to early detect hypertension to prevent more severe complications in the Sambirejo Community Health Center area are possible. Body mass index and smoking factors both are modifiable factors and need to be informed continuously to the community, considering the results of the IFLS- 5 show that Indonesian society's awareness of hypertension is still low. ${ }^{28}$

\section{CONCLUSION}

The distribution of hypertension is more dominant in the male group, and $\geq 40$ years of age. Determinants of hypertension are age, gender, genetics, exercise habits, smoking habits, fruit and vegetable consumption, and body mass index. We found that genetic factors are the most dominant determinant. 


\section{CONFLICT OF INTEREST}

There is no conflict of interest in this research and publication.

\section{Acknowledgement}

The researcher thanked Dr. Sri Herawati, M.M. (Head of Sambirejo Community Health Center, Sragen Regency) who has permitted this research. The researcher also thanked the young doctors of FK UII who helped in the data collection, namely Fitrizha Rachmadea, Ayu Kurnia, Abrid Farahnaz, Sitty Amalia, Mira Sagita and Alifa Astuti.

\section{REFERENCES}

1. O U AP, F UC, F EO, O C AC. Epidemiologic Transition of Diseases and Health-Related Events in Developing Countries: A Review. American Journal of Medicine and Medical Sciences [Internet]. 2015;2015(4):150-7.

2. Kementrian Kesehatan RI. Riset Kesehatan Dasar (RISKESDAS). Laporan Nasional 2013. 2013. 1-384 p.

3. Kemkes. Cegah dan kendalikan penyakit ginjal dengan cerdik dan patuh. 2018. 3-5 p.

4. Yang MH, Kang SY, Lee JA, Kim YS, Sung EJ, Lee KY, et al. The effect of lifestyle changes on blood pressure control among hypertensive patients. Korean Journal of Family Medicine. 2017;38(4):173-80.

5. M. Sopiyudin Dahlan. Statistik untuk Kedokteran dan Kesehatan: Deskriptif, Bivariat, dan Multivariat (Statistic for Medicine and Health Science: Descriptive, Bivariate, and Multivariate). 2015.

6. Kemenkes RI. Penerapan Pola Konsumsi Makanan dan Aktivitas Fisik [Internet]. Strategi Nasional Penerapan Pola Konsumsi Makanan dan Aktivitas FIsik. 2011.

7. Amelia R, Nasrul E, Basyar M. Artikel Penelitian Hubungan Derajat Merokok Berdasarkan Indeks Brinkman dengan Kadar Hemoglobin. Jurnal Kesehatan Andalas. 2016;5(3):619-24.

8. Kementerian Kesehatan RI. Buku Saku Pemantauan Status Gizi ( PSG ) Tahun 2017; Hasil Pemantauan Status Gizi. Jakarta; 2018.
9. Kemenkes RI. Pedoman Gizi Seimbang (Nutritional guidelines). Direktorat Jenderal Bina Gizi dan KIA. 2014.

10. Muhadi. NC 8: Evidence-based Guideline Penanganan Pasien Hipertensi Dewasa. CDKJournal. 2016;43(1):54-9.

11. Komukai K, Mochizuki S, Yoshimura M. Gender and the renin-angiotensin-aldosterone system. Fundamental and Clinical Pharmacology. 2010;24(6):687-98.

12. Mishra JS, Hankins GD, Kumar S. Testosterone downregulates angiotensin II type-2 receptor via androgen receptor-mediated ERK1/2 MAP kinase pathway in rat aorta. JRAAS - Journal of the Renin-Angiotensin-Aldosterone System. 2016;17(4):1-9.

13. Singh S, Shankar R, Singh GP. Prevalence and Associated Risk Factors of Hypertension: A Cross-Sectional Study in Urban Varanasi. International Journal of Hypertension. 2017;2017:1-10.

14. Eshkoor S, Hamid T, Shahar S, Ng C, Mun C. Factors Affecting Hypertension among the Malaysian Elderly. Journal of Cardiovascular Development and Disease [Internet]. 2016;3(1):8.

15. Jankowski P, Czarnecka D. Pulse Pressure, Blood Flow, and Atherosclerosis. American Journal of Hypertension. 2012;25(10):1040-1.

16. Chandra A, Neeland IJ, Berry JD, Ayers CR, Rohatgi A, Das SR, et al. The relationship of body mass and fat distribution with incident hypertension: Observations from the dallas heart study. Journal of the American College of Cardiology. 2014;64(10):9971002.

17. James PA. Evidence-based guideline for the management of high blood pressure in adults. Jama [Internet]. 2014;311(5):50720.

18. Abtahi F, Kianpour Z, Zibaeenezhad M, Naghshzan A, Heydari S, Beigi MB, et al. Correlation between Cigarette Smoking and Blood Pressure and Pulse Pressure among Teachers Residing in Shiraz, Southern Iran. Iranian Cardiovascular Research Journal Iran Cardiovasc Res J [Internet]. 2011;55(33):97-102. 
19. Ehret GB, Caulfield MJ. Genes for blood pressure: An opportunity to understand hypertension. European Heart Journal. 2013;34(13):951-61.

20. Sarkar T, Pal Singh N. Epidemiology and genetics of hypertension. Journal of Association of Physicians of India. 2015;63(September 2015):61-8.

21. Hermina H, S P. Gambaran Konsumsi Sayur dan Buah Penduduk Indonesia dalam Konteks Gizi Seimbang: Analisis Lanjut Survei Konsumsi Makanan Individu (SKMI) 2014. Vol. 44, Buletin Penelitian Kesehatan. 2016.

22. Zheng J, Zhou Y, Li S, Zhang P, Zhou T, Xu DP, et al. Effects and mechanisms of fruit and vegetable juices on cardiovascular diseases. International Journal of Molecular Sciences. 2017;18(3).

23. Rahmayanti E, Sutjiati E. Anjuran Kombinasi Diet DASH (Dietary Approaches To Stop Hypertension) Dan Diet Rendah Garam Pada Wanita Menapouse Dengan Hipertensi. Jurnal Kesehatan. 2009;7(2):100-18.

24. Hepti Muliyati*, Aminuddin Syam SS. Hubungan Pola Konsumsi Natrium Dan Kalium Serta Aktifitas Fisik Dengan Kejadian Hipertensi Pada Pasien Rawat Jalan Di Rsup Dr. Wahidin Sudirohusodo Makassar. Media Gizi Masyarakat Indonesia. 2011;1:1-7.

25. AHA. American Heart Association Recommendations for Physical Activity in Adults and Kids [Internet]. Healthy Living - Fitness Basics. 2018. Available from: https:// www.heart.org/en/healthy-living/fitness/ fitness-basics/aha-recs-for-physical-activity-in-adults

26. Préda I. Physical activity, sport and hypertension = Fizikai aktivitás, sport és hipertonia. Testnevelés, Sport, Tudomány. 2017;1(2):30-4.

27. Kishore J, Gupta N, Kohli C, Kumar N. Prevalence of Hypertension and Determination of Its Risk Factors in Rural Delhi. International Journal of Hypertension. 2016;2016:1-6.

28. Peltzer K, Pengpid S. The Prevalence and Social Determinants of Hypertension among Adults in Indonesia: A Cross-Sectional Population-Based National Survey.
International Journal of Hypertension. 2018;2018:1-9. 